\title{
Recent advances in the molecular epidemiology of clinical
}

\section{malaria [version 1; peer review: 4 approved]}

\author{
Mario Recker (iD), Peter C Bull2, Caroline O Buckee \\ ${ }^{1}$ Centre for Mathematics and the Environment, University of Exeter, Penryn Campus, Penryn, TR10 9FE, UK \\ ${ }^{2}$ Department of Pathology, University of Cambridge, Cambridge, CB2 1QP, UK \\ ${ }^{3}$ Center for Communicable Disease Dynamics, Harvard T.H. Chan School of Public Health, Boston, MA, 02115, USA
}

V1 First published: 30 Jul 2018, 7(F1000 Faculty Rev):1159

https://doi.org/10.12688/f1000research.14991.1

Latest published: 30 Jul 2018, 7(F1000 Faculty Rev):1159

https://doi.org/10.12688/f1000research.14991.1

\section{Abstract}

Human malaria is a complex disease that can show a wide array of clinical outcomes, from asymptomatic carriage and chronic infection to acute disease presenting various life-threatening pathologies. The specific outcome of an infection is believed to be determined by a multifactorial interplay between the host and the parasite but with a general trend toward disease attenuation with increasing prior exposure. Therefore, the main burden of malaria in a population can be understood as a function of transmission intensity, which itself is intricately linked to the prevalence of infected hosts and mosquito vectors, the distribution of infection outcomes, and the parasite population diversity. Predicting the long-term impact of malaria intervention measures therefore requires an in-depth understanding of how the parasite causes disease, how this relates to previous exposures, and how different infection pathologies contribute to parasite transmission. Here, we provide a brief overview of recent advances in the molecular epidemiology of clinical malaria and how these might prove to be influential in our fight against this important disease.

\section{Keywords}

malaria, epidemiology, severe disease, natural acquired immunity, infectivity

\section{Open Peer Review \\ Approval Status \\ 1

$2 \quad 3 \quad 4$ \\ version 1 \\ 30 Jul 2018 \\ Faculty Reviews are review articles written by the prestigious Members of Faculty Opinions. The articles are commissioned and peer reviewed before publication to ensure that the final, published version is comprehensive and accessible. The reviewers who approved the final version are listed with their names and affiliations.}

1. Roly D Gosling, University of California San Francisco, San Francisco, USA

2. Melissa Penny, Swiss Tropical and Public Health Institute, Basel, Switzerland

3. Gerry F. Killeen, Ifakara Health Institute, Dar es Salaam, Tanzania

Liverpool School of Tropical Medicine, Liverpool, UK

4. Patrick E Duffy, National Institute of Allergy and Infectious Diseases, NIH, Rockville, USA Any comments on the article can be found at the end of the article. 
Corresponding author: Mario Recker (m.recker@exeter.ac.uk)

Author roles: Recker M: Writing - Original Draft Preparation, Writing - Review \& Editing; Bull PC: Writing - Original Draft Preparation, Writing - Review \& Editing; Buckee CO: Writing - Original Draft Preparation, Writing - Review \& Editing

Competing interests: No competing interests were disclosed.

Grant information: MR is supported by the Medical Research Council (grant MR/M003906/1).

The funders had no role in study design, data collection and analysis, decision to publish, or preparation of the manuscript.

Copyright: $\odot 2018$ Recker $\mathrm{M}$ et al. This is an open access article distributed under the terms of the Creative Commons Attribution License, which permits unrestricted use, distribution, and reproduction in any medium, provided the original work is properly cited.

How to cite this article: Recker M, Bull PC and Buckee CO. Recent advances in the molecular epidemiology of clinical malaria [version 1; peer review: 4 approved] F1000Research 2018, 7(F1000 Faculty Rev):1159 https://doi.org/10.12688/f1000research.14991.1

First published: 30 Jul 2018, 7(F1000 Faculty Rev):1159 https://doi.org/10.12688/f1000research.14991.1 


\section{Background}

Malaria is caused by the mosquito-transmitted protozoan parasite Plasmodium spp. There are five species known to infect humans: $P$. falciparum, $P$. vivax, $P$. malariae, $P$. ovale, and $P$. knowlesi, of which $P$. falciparum malaria is the most virulent form, causing the most morbidity and mortality in humans, and thus will be the focus here. Despite continual control efforts over the last 50 years or more, the burden of disease is still substantial, and recent estimates put the annual number of malaria cases in the region of more than 200 million, leading to over 400,000 deaths, predominantly in young children living in sub-Saharan Africa ${ }^{1}$. The first licensed malaria vaccine (RTS,S) has shown limited efficacy ${ }^{2}$ and currently is introduced as only a pilot scheme in a few settings in sub-Saharan Africa. The main disease intervention therefore still relies on drug treatment of patients and prevention of exposure by (insecticide-treated) bed nets, spraying of houses with insecticides, and other general mosquito control measures. Following a large scale-up of vector control in combination with artemisinin combination therapy, there has been an overall reduction in the number of malaria cases over the last decade $^{3}$. However, this reduction does not always correspond well with known control measures ${ }^{4}$ and shows significant geographic variations. For example, big reductions have been achieved in Southeast Asia and the Western Pacific, whereas several regions in the Americas and Africa have experienced no change or even an increase in cases in recent years ${ }^{1,5}$.

The challenges in malaria control are manifold, and, even in regions where a drastic reduction has been achieved and where local elimination is theoretically possible, maintaining a diseasefree state without achieving a similar reduction in neighboring regions will be difficult. Underlying these challenges is a lack of understanding of the basic biology of malaria transmission and its relationship to the epidemiological patterns of infection and disease in different transmission settings. In particular, not all infections cause severe clinical symptoms, and most infections contributing to transmission in a given location cause only mild illness or are classified as asymptomatic (but see 6 for a critical discussion on the terminology of "asymptomatic" malaria). Intervention-induced changes in parasite transmission therefore will incur shifts in the age distributions of particular age- and exposure-dependent disease manifestations in complex ways $\mathrm{s}^{7,8}$. Predicting the epidemiological outcome of control measures therefore requires a more in-depth knowledge of the factors responsible for severe malaria as well as a better understanding of who is currently infected and who contributes to transmission.

\section{What causes severe malaria?}

Malaria infections are initiated by the bite of an infectious mosquito, which releases sporozoites into the bloodstream that subsequently travel to, and undergo differentiation into merozoites in, the liver. After multiple rounds of multiplication within infected liver cells, merozoites are released into the bloodstream, starting a cycle of repeated invasion and multiplication within red blood cells (RBCs) that leads, both directly and indirectly, to considerable cell destruction. In addition to anemia as a direct result of RBC loss, splenic clearance of uninfected RBCs, and reduced RBC production, malaria pathology is often caused by parasites sequestering in the deep vasculature, leading to local inflammation, hemorrhages, tissue damage, and obstruction of blood flow. Sequestration itself is the result of infected RBCs (iRBCs) adhering to a number of different host endothelial cell receptors $^{9-12}$ through highly polymorphic parasite proteins called PfEMP $1^{13}$ that are encoded by the var multigene family ${ }^{14}$ and inserted into the surface of iRBCs. The prominent expression of these proteins on the surface of iRBCs makes them key targets for adaptive immune responses, which the parasite escapes by exploiting the enormous sequence variation of var genes both between multiple variant var gene copies within individual parasites and between repertoires of var genes within parasite populations. In one of the most sophisticated immune-evasion strategies studied, the parasite can switch between different PfEMP1 types during infection in a process referred to as clonal antigenic variation ${ }^{15,16}$.

Despite its diversity, PfEMP1 plays a central role as a target of naturally acquired immunity (NAI). Over years of repeated infections, individuals living in malaria-endemic areas acquire a repertoire of PfEMP1 variant-specific immune responses through repeated infections that are believed to confer protection from life-threatening disease (reviewed in 17). In a clear illustration of the importance of PfEMP1 as immune targets, women in their first pregnancy who have grown up in malaria-endemic areas and who have gained immunity to severe malaria temporarily lose this immunity because their placentas open up a novel niche for parasite sequestration. This is exploited by a single functionally and immunologically distinct PfEMP1 type, VAR2CSA (see below), which is present in every parasite genome and to which immunity is rapidly gained ${ }^{18}$.

So far, the high diversity of PfEMP1 has precluded this family of molecules from being considered a serious vaccine target. However, the discovery that certain disease manifestations are associated with the expression of restricted subsets of PfEMP1 variants has opened up the debate of whether an anti-disease or anti-virulence vaccine in fact might be a feasible option ${ }^{19}$. One of the first and so far most robust examples is the involvement of a particular PfEMP1 variant in pregnancy-associated malaria, mediated by the binding of VAR2CSA-expressing iRBCs to placental chondroitin sulfate A $(\mathrm{CSA})^{20}$. The fact that this protein appears unusually conserved is now being exploited in the design of the first placental malaria vaccines that are currently undergoing clinical tests ${ }^{21,22}$.

This functional subdivision of var genes can be extended to those that are involved in childhood malaria. For example, based on upstream promoter sequence (Ups), var genes can be divided into three groups-UpsA, UpsB, and UpsC—of which UpsA genes are frequently found to be upregulated during severe infection, particularly in young children. Although sequence diversification within this UpsA group of genes appears to be more restricted than others, they are still too diverse as a whole to be considered potential vaccine targets. As such, the recent discovery that a much smaller gene subset, those containing specific domain types called CIDR $\alpha 1$, and their binding to the 
endothelial protein $\mathrm{C}$ receptor (EPCR) appeared to be associated with cerebral malaria caused great excitement ${ }^{23-26}$. In fact, confidence in the importance of this interaction underlying severe infection outcomes is such that it is now being promoted as a potential anti-disease vaccine target ${ }^{19}$.

However, the crux of the problem is that, in most cases, findings are based on observed associations between pathological outcomes and the proportional expression of gene variants within the infecting parasite population sampled from peripheral blood rather than directly from parasites that are sequestered in tissues. The issues with these kinds of studies are further compounded by the enormous technical challenge of fully taking into account individuals' exposure histories and therefore their immune status at the time of infection. This means that caution has to be exercised when trying to infer causality, which was recently re-emphasized by Azasi et al., who found that in vitro iRBC binding to endothelial cells is often independent of EPCR and can easily be interrupted under flow conditions ${ }^{27}$. Approaches to gain a better understanding of the host-parasite interaction in capillaries include (1) improved understanding of the parasites actually responsible for pathology through direct sampling of sequestered parasites in different tissues by either using skin biopsies in patients ${ }^{28}$ or sampling from tissues post-mortem ${ }^{29}$; (2) improved assessment of parasite sequestration in tissues through direct observation of parasites within capillaries through mucosal surfaces to correlate capillary congestion with disease outcome ${ }^{30}$; (3) seeking associations between peripheral parasite gene expression levels and direct measures of sequestration through malarial retinopathy ${ }^{25,31}$; and (4) improved understanding of the role of NAI in shaping the infecting parasite population by seeking associations between peripheral parasite gene expression levels and pre-existing antibody responses in controlled human infections of volunteers with differing levels of natural exposure to infection ${ }^{32}$.

\section{Who is infected and who contributes to transmission?} As the outcome of an infection is partially determined by an individual's exposure history to the parasite, elucidating the clinical epidemiology of malaria requires an understanding of a region's (spatially and time-varying) transmission intensity and therefore knowledge of who is currently infected, who contributes to transmission, and how much. However, measuring disease prevalence and relating this prevalence to transmission remain important challenges that can be severely hampered by the relatively high proportion of clinically silent and lowparasite density infections, especially in highly endemic settings. With the improvement of molecular methods for parasite detection, it has become increasingly clear that microscopystill the gold standard for diagnosis in many placessystematically misses a large number of low-density infections. Microscopy detects parasite densities in the blood of greater than about 100 parasites per microliter, a detection threshold similar to that of rapid diagnostic tests, but misses an average of half of all malaria infections compared with standard polymerase chain reaction $(\mathrm{PCR})^{33}$. Paradoxically, this appears to be the case regardless of transmission setting or exposure/ immunity, and a higher fraction of submicroscopic infections occur in low-transmission settings. Indeed, it has been estimated that in areas with less than $10 \%$ prevalence by PCR, $88 \%$ of infections would not be detected by microscopy ${ }^{33}$. Recent ultrasensitive PCR techniques ${ }^{34}$ have lowered this detection limit even further to 22 parasites per milliliter, which has led to researchers confirming the substantial reservoir of low-density infections. In the absence of molecular methods for routine surveillance, understanding the relationship between clinical cases (which form the basis of surveillance in most endemic countries) and overall prevalence of infection remains a key challenge.

The prevalence of infection is not the only consideration for defining transmission, however. Many infections are composed of multiple parasite clones, and new infections often occur and cause new episodes of disease against the backdrop of ongoing asymptomatic parasitemia. This means that even with accurate estimates of the fraction of infected people, we are still unable to describe the incidence or force of infection, which is related to the number of new infections over time. The enormous genomic diversity of the parasite, coupled with the frequency of low-density infections, makes it difficult to detect how many clones each infection is composed of, and there are few robust strain markers with which to follow chains of transmission. Recently, new sequencing methods and accompanying analytical tools have shed light on the extent of superinfection, revealing substantial "complexity of infection", particularly in hightransmission settings like Uganda where individuals can harbor up to 20 clones $^{35}$. One result of these findings is a move toward the concept of using the molecular force of infection (molFOI), which measures the number of new genotypes acquired by individuals over time ${ }^{36}$, to define transmission settings. An added value of these highly sensitive diagnostic tools is that they allow tracking of the genetic relatedness between parasites or infections and, with it, the identification of transmission chains and focal transmission areas. The latter will be particularly important for regions that are nearing malaria elimination and where the monitoring and characterization of residual transmission will be key for sustained malaria control.

The surveillance issues described above are all designed to measure asexual parasites in the blood, which cause the clinical manifestations of malaria but cannot be transmitted to mosquitoes. This means that quantifying the infectious reservoir requires different approaches. Only a small fraction of blood-stage parasites develop into male and female gametocytes, the sexual parasite stages that are taken up during a blood meal and underlie infectiousness. The molecular pathways responsible for the switch to sexual development and the dynamics of gametocytes in the body, as well as their relationship to transmission, are still mysterious ${ }^{37}$. Furthermore, early notions that directly relate asexual parasitemia with infectivity, which implied that young individuals suffering from severe disease are by far the highest contributor to malaria transmission, have also been put into question by revealing that asymptomatic infections contribute significantly more to transmission than previously thought ${ }^{38-40}$. For example, a recent study in Ethiopia used mosquito blood-feeding experiments to establish that only $15 \%$ 
of $P$. falciparum-infected individuals were infectious and that asexual parasitemia was not correlated with infectiousness ${ }^{40}$. Earlier findings that gametocytes are not homogeneously distributed within the blood and may cluster under the skin to promote transmission ${ }^{41,42}$, plus the considerable uncertainties associated with the determinants of parasite fitness in the mosquito as it transitions from sexual gametocytes to infectious sporozoites, mean that there are still some outstanding difficulties in quantitatively linking standard measures of prevalence with transmission intensity.

\section{Going forward}

The identification of EPCR-binding phenotypes and their potential involvement in cerebral malaria has caused excitement and raised some optimism about the possibility of developing an anti-disease vaccine. However, for a convincing case to be made, one still needs to unambiguously demonstrate the causal link between host receptor binding and specific disease manifestations. A crucial point here is that every parasite contains in its repertoire most, if not all, of these "disease-causing", or rather disease-associated, variants. That is, if the parasite has the freedom to express its entire PfEMP1 antigenic repertoire during infection, what determines the actual outcome? It has been shown that PfEMP1 expression is hierarchical ${ }^{43,44}$ and that host immune responses have an influence on what variants are expressed during infection ${ }^{32,45}$. However, this alone cannot explain why an infection causes cerebral malaria in one child but severe malarial anemia in another. Furthermore, the observed hierarchical expression of var genes may be due simply to the existence of alternative molecular strategies used by the parasites to evade immune responses in individuals of different levels of immunity. There are reported examples of asymptomatic infections that exhibit high levels of expression of group A-like var genes previously found to be associated with severe malaria, which suggests that the PfEMP1 antigens they encode can play a role in the maintenance of chronic infections ${ }^{46}$. At this point, more integrated (that is, systems and -omics) approaches should be able to offer more detailed information about the specific immunological and parasitological processes involved in the progression toward disease, especially when taking into consideration the composition of the infecting parasite population in relation to the host's immune history (see 47 and 48 for recent examples).

More advanced approaches are also required for improving our understanding of NAI to malaria. Crucially, this necessitates (1) a clear definition of what constitutes protection and (2) robust and measurable correlates of protection, neither of which are straightforward. As mentioned above, NAI has to be considered as a multi-stage process or even a continuum whereby infection severity generally attenuates with cumulative exposure to infection. Numerous studies have tried to find correlates of protection by means of prospective cohort studies in which individuals' immune responses to predefined panels of antigens are correlated with the incidence of clinical episodes. One of the main problems with these studies is the often small effect size, leading to contradictory findings and poor reproducibility (reviewed in 49). This is further complicated by the lack of reliable measures of how often an individual has been challenged in the past, which is an essential consideration given that the needle of protective responses and the haystack of non-protective responses, as well as NAI itself, all increase with cumulative exposure to infection. Furthermore, condensing this multifaceted process into a binary phenotype (protected or not) bypasses some of the aforementioned complexities underlying malaria pathology and NAI and thus is unlikely to provide a comprehensive picture of the myriad of processes involved.

In that respect, it is also imperative to embrace more sophisticated methods to analyze increasingly complex datasets. Machine learning approaches offer a number of advantages over more traditional, univariate analyses in their ability to extract non-linear relationships and interactions from high-dimensional data in a hypothesis-free manner. For example, in a recent study, we used a machine learning approach to identify predictive signatures of clinical protection from protein microarray data containing thousands of measured immune markers ${ }^{50}$. In another study, Helb et al. used a predictive framework based on machine learning to estimate recent exposure to the malaria parasite $^{51}$. However, these powerful methods crucially rely on detailed and robust datasets that permit appropriate crossvalidation and verification of research findings. One important step forward in that direction is the use of ensemble datasets across a wide range of studies, as was recently advocated in order to better define the infectious reservoir and measure transmission more accurately ${ }^{52}$.

Finally, a more improved understanding of the biology of mosquito-human and human-mosquito transmission needs to include better knowledge of local vector ecologies. Surprisingly, we still know relatively little about how changes in mosquito abundance and species distributions over the last few years and decades-some of the most important determinants of malaria epidemiology-might have not only influenced but actively shaped some of the observed changes in malaria incidence. Unfortunately, detailed and long-term surveillance data on vector distribution are scarce and are available for only a small number of vector species and epidemiological settings. Therefore, large-scale vector sequencing initiatives, such as the malariaGEN 1000 genomes project ${ }^{53}$, together with more detailed investigations into the behavioral and ecological factors underlying this part of the transmission cycle, will have a central role to play in developing a fine-grained and holistic understanding of malaria epidemiology that incorporates the Plasmodium parasite, the human host, and the mosquito vector.

Competing interests

The authors declare that they have no competing interests.

Grant information

MR is supported by the Medical Research Council (grant MR/ M003906/1).

The funders had no role in study design, data collection and analysis, decision to publish, or preparation of the manuscript. 
1. WHO Malaria Report: World malaria report 2017. 2017. Reference Source

2. F Olotu A, Fegan G, Wambua J, et al.: Seven-Year Efficacy of RTS,S/AS01 Malaria Vaccine among Young African Children. N Engl J Med. 2016; 374(26): 2519-29.

PubMed Abstract | Publisher Full Text | Free Full Text | F1000 Recommendation

3. $\mathrm{F}$ Bhatt S, Weiss DJ, Cameron E, et al.: The effect of malaria control on Plasmodium falciparum in Africa between 2000 and 2015. Nature. 2015; 526(7572): 207-11.

PubMed Abstract | Publisher Full Text | Free Full Text | F1000 Recommendation

4. F Snow RW, Sartorius B, Kyalo D, et al:: The prevalence of Plasmodium falciparum in sub-Saharan Africa since 1900. Nature. 2017; 550(7677): 515-8. PubMed Abstract | Publisher Full Text | Free Full Text | F1000 Recommendation

5. F Nkumama IN, O'Meara WP, Osier FHA: Changes in Malaria Epidemiology in Africa and New Challenges for Elimination. Trends Parasitol. 2017; 33(2): $128-40$.

PubMed Abstract | Publisher Full Text | F1000 Recommendation

6. F Chen I, Clarke SE, Gosling R, et al.: "Asymptomatic" Malaria: A Chronic and Debilitating Infection That Should Be Treated. PLoS Med. 2016; 13(1): e1001942. PubMed Abstract | Publisher Full Text | Free Full Text | F1000 Recommendation

7. $\quad F$ Mogeni P, Williams TN, Fegan G, et al:: Age, Spatial, and Temporal Variations in Hospital Admissions with Malaria in Kilifi County, Kenya: A 25Year Longitudinal Observational Study. PLoS Med. 2016; 13(6): e1002047. PubMed Abstract | Publisher Full Text | Free Full Text | F1000 Recommendation

8. Roca-Feltrer A, Carneiro I, Smith L, et al:: The age patterns of severe malaria syndromes in sub-Saharan Africa across a range of transmission intensities and seasonality settings. Malar J. 2010; 9: 282. PubMed Abstract | Publisher Full Text | Free Full Text

9. Barnwell JW, Asch AS, Nachman RL, et al:: A human 88-kD membrane glycoprotein (CD36) functions in vitro as a receptor for a cytoadherence ligand on Plasmodium falciparum-infected erythrocytes. J Clin Invest. 1989; 84(3): 765-72.

PubMed Abstract | Publisher Full Text | Free Full Text

10. Berendt AR, Simmons DL, Tansey J, et al:: Intercellular adhesion molecule-1 is an endothelial cell adhesion receptor for Plasmodium falciparum. Nature. 1989; 341(6237): 57-9.

PubMed Abstract | Publisher Full Text

11. David PH, Handunnetti SM, Leech JH, et al.: Rosetting: a new cytoadherence property of malaria-infected erythrocytes. Am J Trop Med Hyg. 1988; 38(2): 289-97.

PubMed Abstract | Publisher Full Text

12. Oquendo $P$, Hundt $E$, Lawler J, et al:: CD36 directly mediates cytoadherence of Plasmodium falciparum parasitized erythrocytes. Cell. 1989; 58(1): 95-101. PubMed Abstract | Publisher Full Text

13. Baruch DI, Ma XC, Singh HB, et al:: Identification of a region of PfEMP1 that mediates adherence of Plasmodium falciparum infected erythrocytes to CD36: conserved function with variant sequence. Blood. 1997; 90(9): 3766-75. PubMed Abstract

14. Su XZ, Heatwole VM, Wertheimer SP, et al.: The large diverse gene family var encodes proteins involved in cytoadherence and antigenic variation of Plasmodium falciparum-infected erythrocytes. Cell. 1995; 82(1): 89-100. PubMed Abstract

15. Roberts DJ, Craig AG, Berendt AR, et al.: Rapid switching to multiple antigenic and adhesive phenotypes in malaria. Nature. 1992; 357(6380): 689-92. PubMed Abstract | Publisher Full Text | Free Full Text

16. Scherf A, Lopez-Rubio JJ, Riviere L: Antigenic variation in Plasmodium falciparum. Annu Rev Microbiol. 2008; 62: 445-70. PubMed Abstract | Publisher Full Text

17. Langhorne J, Ndungu FM, Sponaas AM, et al:: Immunity to malaria: more questions than answers. Nat Immunol. 2008; 9(7): 725-32. PubMed Abstract | Publisher Full Text

18. Salanti A, Dahlbäck M, Turner $L$, et al.: Evidence for the involvement of VAR2CSA in pregnancy-associated malaria. J Exp Med. 2004; 200(9): 1197-203. PubMed Abstract | Publisher Full Text | Free Full Text

19. $\mathrm{F}$ Lennartz F, Lavstsen T, Higgins MK: Towards an anti-disease malaria vaccine. Emerg Top Life Sci. 2017; 1(6): 539-45. Publisher Full Text | F1000 Recommendation

20. Fried M, Duffy PE: Adherence of Plasmodium falciparum to chondroitin sulfate A in the human placenta. Science. 1996; 272(5267): 1502-4 PubMed Abstract | Publisher Full Text

21. F Fried M, Duffy PE: Designing a VAR2CSA-based vaccine to prevent placental malaria. Vaccine. 2015; 33(52): 7483-8.

PubMed Abstract | Publisher Full Text | Free Full Text | F1000 Recommendation

22. Pehrson C, Salanti A, Theander TG, et al:: Pre-clinical and clinical development of the first placental malaria vaccine. Expert Rev Vaccines. 2017; 16(6): 613-24. PubMed Abstract | Publisher Full Text
23. F Turner L, Lavstsen T, Berger SS, et al:: Severe malaria is associated with parasite binding to endothelial protein C receptor. Nature. 2013; $498(7455)$ : 502-5.

PubMed Abstract | Publisher Full Text | Free Full Text | F1000 Recommendation

24. F Tuikue Ndam N, Moussiliou A, Lavstsen T, et al: Parasites Causing Cerebral Falciparum Malaria Bind Multiple Endothelial Receptors and Express EPCR and ICAM-1-Binding PfEMP1. J Infect Dis. 2017; 215(12): 1918-25. PubMed Abstract | Publisher Full Text | F1000 Recommendation

25. F Shabani E, Hanisch B, Opoka RO, et al:: Plasmodium falciparum EPCRbinding PfEMP1 expression increases with malaria disease severity and is elevated in retinopathy negative cerebral malaria. BMC Med. 2017; 15(1): 183 PubMed Abstract | Publisher Full Text | Free Full Text | F1000 Recommendation

26. F Bernabeu M, Smith JD: EPCR and Malaria Severity: The Center of a Perfect Storm. Trends Parasitol. 2017; 33(4): 295-308.

PubMed Abstract | Publisher Full Text | Free Full Text | F1000 Recommendation

27. F Azasi $Y$, Lindergard G, Ghumra A, et al.: Infected erythrocytes expressing DC13 PfEMP1 differ from recombinant proteins in EPCR-binding function. Proc Natl Acad Sci U S A. 2018; 115(5): 1063-8.

PubMed Abstract | Publisher Full Text | Free Full Text | F1000 Recommendation

28. Moxon CA, Wassmer SC, Milner DA Jr, et al.: Loss of endothelial protein C receptors links coagulation and inflammation to parasite sequestration in cerebral malaria in African children. Blood. 2013; 122(5): 842-51. PubMed Abstract | Publisher Full Text | Free Full Text

29. Montgomery J, Mphande FA, Berriman M, et al.: Differential var gene expression in the organs of patients dying of falciparum malaria. Mol Microbiol. 2007; 65(4) 959-67.

PubMed Abstract | Publisher Full Text | Free Full Text

30. $\mathrm{F}$ Dondorp $\mathrm{AM}$, Ince $\mathrm{C}$, Charunwatthana $\mathrm{P}$, et al:: Direct in vivo assessment of microcirculatory dysfunction in severe falciparum malaria. $J$ Infect Dis. 2008; 197(1): 79-84.

PubMed Abstract | Publisher Full Text | F1000 Recommendation

31. Abdi Al, Kariuki SM, Muthui MK, et al: Differential Plasmodium falciparum surface antigen expression among children with Malarial Retinopathy. Sci Rep. $2015 ; 5$ : 18034 .

PubMed Abstract | Publisher Full Text | Free Full Text

32. Abdi Al, Hodgson SH, Muthui MK, et al.: Plasmodium falciparum malaria parasite var gene expression is modified by host antibodies: longitudinal evidence from controlled infections of Kenyan adults with varying natural exposure. BMC Infect Dis. 2017; 17(1): 585 .

PubMed Abstract | Publisher Full Text | Free Full Text

33. Okell LC, Bousema T, Griffin JT, et al:: Factors determining the occurrence of submicroscopic malaria infections and their relevance for control. $\mathrm{Nat}$ Commun. 2012; 3: 1237.

PubMed Abstract | Publisher Full Text | Free Full Text

34. $\mathrm{F}$ Imwong $\mathrm{M}$, Hanchana S, Malleret $\mathrm{B}$, et al:: High-throughput ultrasensitive molecular techniques for quantifying low-density malaria parasitemias. $J$ Clin Microbiol. 2014; 52(9): 3303-9.

PubMed Abstract | Publisher Full Text | Free Full Text | F1000 Recommendation

35. Chang HH, Worby CJ, Yeka A, et al.: THE REAL McCOIL: A method for the concurrent estimation of the complexity of infection and SNP allele frequency for malaria parasites. PLOS Comput Biol. 2017; 13(1): e1005348.

PubMed Abstract | Publisher Full Text | Free Full Text

36. Mueller I, Schoepflin S, Smith TA, et al.: Force of infection is key to understanding the epidemiology of Plasmodium falciparum malaria in Papua New Guinean children. Proc Natl Acad Sci U S A. 2012; 109(25): 10030-5. PubMed Abstract | Publisher Full Text | Free Full Text

37. Nilsson SK, Childs LM, Buckee C, et al:: Targeting Human Transmission Biology for Malaria Elimination. PLoS Pathog. 2015; 11(6): e1004871. PubMed Abstract | Publisher Full Text | Free Full Text

38. F Gonçalves BP, Drakeley C, Bousema T: Infectivity of Microscopic and Submicroscopic Malaria Parasite Infections in Areas of Low Malaria Endemicity. J Infect Dis. 2016; 213(9): 1516-7. PubMed Abstract | Publisher Full Text | F1000 Recommendation

39. F Vantaux A, Samreth R, Piv E, et al:: Contribution to Malaria Transmission of Symptomatic and Asymptomatic Parasite Carriers in Cambodia. $J$ Infect Dis. 2018; 217(10): 1561-8

PubMed Abstract | Publisher Full Text | F1000 Recommendation

40. F Tadesse FG, Slater HC, Chali W, et al.: The Relative Contribution of Symptomatic and Asymptomatic Plasmodium vivax and Plasmodium falciparum Infections to the Infectious Reservoir in a Low-Endemic Setting in Ethiopia. Clin Infect Dis. 2018; 66(12): 1883-91. PubMed Abstract | Publisher Full Text | F1000 Recommendation

41. Chardome M, Janssen PJ: [Inquiry on malarial incidence by the dermal method in the region of Lubilash, Belgian Congo]. Ann Soc Belg Med Trop (1920). 1952; 32(3): 209-11.

PubMed Abstrac 
42. Pichon G, Awono-Ambene HP, Robert V: High heterogeneity in the number of Plasmodium falciparum gametocytes in the bloodmeal of mosquitoes fed on the same host. Parasitology. 2000; 121(Pt 2): 115-20.

PubMed Abstract | Publisher Full Text

43. Cham GK, Turner L, Lusingu J, et al:: Sequential, ordered acquisition of antibodies to Plasmodium falciparum erythrocyte membrane protein 1 domains. J Immunol. 2009; 183(5): 3356-63. PubMed Abstract | Publisher Full Text

44. Cham GK, Turner L, Kurtis JD, et al:: Hierarchical, domain type-specific acquisition of antibodies to Plasmodium falciparum erythrocyte membrane protein 1 in Tanzanian children. Infect Immun. 2010; 78(11): 4653-9. PubMed Abstract | Publisher Full Text | Free Full Text

45. Bull PC, Pain A, Ndungu FM, et al.: Plasmodium falciparum antigenic variation: relationships between in vivo selection, acquired antibody response, and disease severity. J Infect Dis. 2005; 192(6): 1119-26. PubMed Abstract | Publisher Full Tex

46. Warimwe GM, Recker M, Kiragu EW, et al:: Plasmodium falciparum var gene expression homogeneity as a marker of the host-parasite relationship under different levels of naturally acquired immunity to malaria. PLoS One. 2013; 8(7): e70467.

PubMed Abstract | Publisher Full Text | Free Full Text

47. F Rono MK, Nyonda MA, Simam JJ, et al:: Adaptation of Plasmodium falciparum to its transmission environment. Nat Ecol Evol. 2018; 2(2): 377-87. PubMed Abstract | Publisher Full Text | F1000 Recommendation
48. F Tonkin-Hill GQ, Trianty L, Noviyanti R, et al:: The Plasmodium falciparum transcriptome in severe malaria reveals altered expression of genes involved in important processes including surface antigen-encoding var genes. PLOS Biol. 2018; 16(3): e2004328.

PubMed Abstract | Publisher Full Text | Free Full Text | F1000 Recommendation

49. Fowkes FJ, Richards JS, Simpson JA, et al.: The relationship between antimerozoite antibodies and incidence of Plasmodium falciparum malaria: A systematic review and meta-analysis. PLoS Med. 2010; 7(1): e1000218. PubMed Abstract | Publisher Full Text | Free Full Text

50. F Valletta JJ, Recker M: Identification of immune signatures predictive of clinical protection from malaria. PLoS Comput Biol. 2017; 13(10): e1005812. PubMed Abstract | Publisher Full Text | Free Full Text | F1000 Recommendation

51. F Helb DA, Tetteh KK, Felgner PL, et al.: Novel serologic biomarkers provide accurate estimates of recent Plasmodium falciparum exposure for individuals and communities. Proc Natl Acad Sci U S A. 2015; 112(32): E4438-47. PubMed Abstract | Publisher Full Text | Free Full Text | F1000 Recommendation

52. $\mathrm{F}$ malERA Refresh Consultative Panel on Characterising the Reservoir and Measuring Transmission: malERA: An updated research agenda for characterising the reservoir and measuring transmission in malaria elimination and eradication. PLoS Med. 2017; 14(11): e1002452. PubMed Abstract | Publisher Full Text | Free Full Text | F1000 Recommendation

53. MalariaGEN: Ag1000G

Reference Source 


\section{Open Peer Review}

\section{Current Peer Review Status:}

\section{Editorial Note on the Review Process}

Faculty Reviews are review articles written by the prestigious Members of Faculty Opinions. The articles are commissioned and peer reviewed before publication to ensure that the final, published version is comprehensive and accessible. The reviewers who approved the final version are listed with their names and affiliations.

\section{The reviewers who approved this article are:}

\section{Version 1}

\section{Patrick E Duffy}

Laboratory of Malaria Immunology and Vaccinology, National Institute of Allergy and Infectious Diseases, NIH, Rockville, MD, USA

Competing Interests: No competing interests were disclosed.

\section{Gerry F. Killeen}

${ }^{1}$ Environmental Health and Ecological Sciences Thematic group, Ifakara Health Institute, Dar es Salaam, Tanzania

2 Department of Vector Biology, Liverpool School of Tropical Medicine, Liverpool, UK

Competing Interests: No competing interests were disclosed.

\section{Melissa Penny}

Department of Epidemiology and Public Health, Swiss Tropical and Public Health Institute, Basel, 4051, Switzerland

Competing Interests: No competing interests were disclosed.

\section{Roly D Gosling}

Department of Epidemiology and Biostatistics,Malaria Elimination Initiative, Global Health Group, University of California San Francisco, San Francisco, California, USA

Competing Interests: No competing interests were disclosed. 
The benefits of publishing with F1000Research:

- Your article is published within days, with no editorial bias

- You can publish traditional articles, null/negative results, case reports, data notes and more

- The peer review process is transparent and collaborative

- Your article is indexed in PubMed after passing peer review

- Dedicated customer support at every stage

For pre-submission enquiries, contact research@f1000.com 